\title{
Corpus luteum regression or maintenance: a duel between prostaglandins and interferon tau
}

\author{
Rina Meidan \\ Department of Animal Sciences, The Robert H. Smith Faculty of Agriculture, Food, and Environment, \\ The Hebrew University of Jerusalem, Rehovot 76100, Israel.
}

\begin{abstract}
Summary
The corpus luteum $(\mathrm{CL})$, via progesterone production, plays a central role in the regulation of cyclicity and in the establishment and maintenance of pregnancy in ruminant species. In the absence of an embryonic signal, the $\mathrm{CL}$ will regress functionally and then structurally. Pulses of prostaglandin F2 $\alpha$ (PGF $2 \alpha$ ) from the uterus reach the ovary via the vascular utero-ovarian plexus causing the demise of the $\mathrm{CL}$. Although it is well established that PGF $2 \alpha$ is the principal luteolytic hormone in ruminants, many aspects of its function are still being debated. The successful establishment of pregnancy requires inhibition of uterine PGF $2 \alpha$ actions, prolongation, or maintenance of luteal function and the continuous secretion of progesterone. The conceptus signals its presence by releasing interferon tau (IFNT). IFNT acting directly on the endometrium by various mechanisms and possibly also on the $\mathrm{CL}$ activates antiluteolytic responses that protect the function of the $\mathrm{CL}$. $\mathrm{PGE}_{2}$, synthesized by the endometrium and the $\mathrm{CL}$, could also induce processes that are important for maintenance of luteal function in pregnancy. The mechanisms controlling luteal regression or its maintenance by the coordinated actions of PGF2 $\alpha$, IFNT, and $\mathrm{PGE}_{2}$ are discussed.
\end{abstract}

\section{Introduction}

The corpus luteum $(\mathrm{CL})$ is a transient endocrine gland critically important for reproductive success; it is involved in regulating the estrous cycle and in establishing and maintaining pregnancy due to the production of progesterone $\left(\mathrm{P}_{4}\right)$. The new $\mathrm{CL}$ develops from those cells that remain in the follicle, granulosa and theca cells, which undergo differentiation soon after ovulation; in addition, microvessels from the theca layer invade the granulosa cell layer and extensive angiogenesis ensues (Fraser and Wulff 2001, Miyamoto, et al. 2010). Therefore, the mature $C L$ is eventually composed of multiple, distinctive cell types including steroidogenic cells (small and large luteal cells) and nonsteroidogenic cells (endothelial cells, pericytes, fibrocytes, and immune cells) (Berisha and Schams 2005, Meidan, et al. 2005, O'Shea, et 
al. 1989, Skarzynski, et al. 2013, Wiltbank 1994). In the nonfertile cycle, pulsatile release of prostaglandin $\mathrm{F} 2 \alpha$ (PGF $2 \alpha$ ) is transported from the uterus to the ovary via the vascular uteroovarian plexus (UOP); this initiates a cascade of events that result in rapid loss of steroidogenesis and destruction of the luteal tissue (Berisha, et al. 2004, McCracken, et al. 1972, Niswender, et al. 2000). However, the $C L$ in the early stage of its development is protected from the luteolytic actions of PGF2 $\alpha$. As the principal luteolytic hormone in ruminants (McCracken, et al. 1972, Niswender, et al. 2000, Schams and Berisha 2004), PGF2 $\alpha$ is widely used in reproductive management of farm animals. Despite this and many years of research, the underlying mechanisms associated with luteolysis in general, or with the stage-specific responses to PGF2 $\alpha$, in particular, are not fully understood and are still being explored. Lack of luteolytic response to PGF $2 \alpha$ early in the estrous cycle or incomplete regression of older CL prior to breeding continue to impede fertility (Brusveen, et al. 2009, Ghanem, et al. 2006, Martins, et al. 2011, Ribeiro, et al. 2012). Important novel findings regarding the luteolytic cascade and development of luteolytic capacity have been made in recent years and will be described. The successful establishment of pregnancy requires prolongation or maintenance of luteal function and the continuous secretion of $\mathrm{P}_{4}$. After cows are bred, a decisive moment occurs between days 17 and 21. In pregnant cows, signals from the newly elongating embryo prevent the occurrence of luteolytic PGF2 $\alpha$ pulses and the process of luteolysis, resulting in maintenance of the CL. In women and non-human primates, luteal function is rescued by chorionic gonadotropins; ruminants that do not express the $\beta$-subunits of CG have evolved a unique signaling pathway to prevent PGF $2 \alpha$ release and to maintain luteal function. In these species, recognition and establishment of pregnancy involve interactions between the endometrium and conceptus. In ruminant species, IFN Tau (IFNT) secreted by the trophoblast cells constitutes the pregnancy recognition signal (Bazer, et al. 1997, Hansen, et al. 1999, Roberts 1996, Spencer and Bazer 2004, Thatcher, et al. 1984). However, the precise mechanisms that result in luteal maintenance are still being elucidated, and recently there has been controversy related to the mode of IFNT actions in the uterus and CL. This review summarizes the recent advances in mechanisms that control luteal regression and maintenance.

\section{Corpus luteum regression: the role of prostaglandin F2 $\alpha$}

It is well accepted that pulsatile release of endometrial PGF2 $\alpha$ induces luteolysis in ruminants (McCracken, et al. 1972). A recent study added important information on the mechanism regulating local PGF2 $\alpha$ transport. It was found that pharmacological inhibition of the prostaglandin transporter protein (PGT) prevents PGF2 $\alpha$ pulses being transported from the uterine vein to the ovarian artery and maintains a functional $C L$ (Lee, et al. 2010). The CL is also a site of PGF2 $\alpha$ synthesis; therefore, the role of luteal PGF2 $\alpha$ and its contribution to luteolysis were investigated by several laboratories. The CL contains the rate-limiting enzyme for prostaglandin synthesis Prostaglandin-Endoperoxide Synthase 2 (PTGS2 or cyclooxygenase-2; COX-2) as well as the specific PGF2 $\alpha$ synthases (PTGFS-AKR1B1 and PTGFS-AKR1C3) that convert PGH2 into PGF2 $\alpha$ (Arosh, et al. 2004a). However, the data concerning their specific upregulation around the time of luteolysis in sheep and cows have been inconsistent (Arosh, et al. 2004a, Hayashi, et al. 2003, Lee, et al. 2012b, Wiltbank and Ottobre 2003) and there is lack of definitive proof for the role of luteal PGF2 $\alpha$ in luteolysis.

To gain insight into the luteolytic cascade and to identify PGF $2 \alpha$-induced changes in the transcriptome of bovine CL, PGF2 $\alpha$ responsive vs. PGF2 $\alpha$-refractory CL (d 11 and d 4, respectively) were compared (Mondal, et al. 2011). At 4 and 24 h after PGF2a, 221 (d 4), 661 
(d 11), 248 (d 4), and 1421 (d 11) PGF2 $\alpha$-regulated genes were identified (Table 1). There were specific functional gene categories and pathways (immune related, apoptosis, and others) that were regulated by PGF $2 \alpha$ in $\mathrm{d} 11 \mathrm{CL}$, particularly at $24 \mathrm{~h}$ post injection. This work revealed that a considerable proportion of transcripts (27\%), up-regulated at $4 \mathrm{~h}$ after PGF2 $\alpha$ in the $\mathrm{d}$ 11 bovine $C L$, were also upregulated in $\mathrm{d} 4 \mathrm{CL}$ that failed to regress. This value was reduced to $3 \%$ only $24 \mathrm{~h}$ post injection (Fig. 1 ). The significant, but transient gene expression response on $\mathrm{d} 4$ suggests that although the initial response occurred (at $4 \mathrm{~h}$ ), it was subsequently blocked or failed to amplify (at 24h) (Fig.1) (Mondal, et al. 2011).

Table 1. Differentially expressed genes in day 4 and 11 corpora lutea with increased and decreased mRNA abundance at 4 and $24 \mathrm{~h}$ after PGF $2 \alpha$

\begin{tabular}{llcc}
\hline Day of estrous cycle & Time point & $\begin{array}{c}\text { No. of genes with Increased } \\
\text { mRNAs }\end{array}$ & $\begin{array}{c}\text { No. of genes with } \\
\text { decreased mRNAs }\end{array}$ \\
\hline Day 4 & 4 h after PGF2 $\alpha$ & 204 & 17 \\
& 24 h after PGF2 $\alpha$ & 71 & 177 \\
Day 11 & 4 h after PGF2 $\alpha$ & 532 & 129 \\
& 24 h after PGF2 $\alpha$ & 842 & 579 \\
\hline
\end{tabular}

The values are numbers of differentially expressed genes in day 4 and 11 corpora lutea $(\mathrm{CL}$ ) with increased (fold change $\geq 2.0 ; \mathrm{P}<0.05$ ) and decreased (fold change $\leq 0.5 ; \mathrm{P}<0.05$ ) mRNA abundance relative to $0 \mathrm{~h}$ time point at 4 and $24 \mathrm{~h}$ after PGF $2 \alpha$ administration on day 4 and day 11 of the estrous cycle.

\section{Number of mRNAs increased $4 \mathrm{~h}$ post $\mathrm{PGF}_{2} \alpha$ administration}

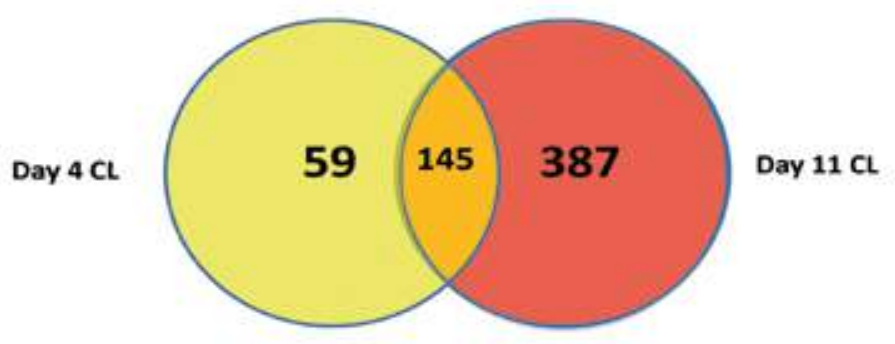

\section{Number of mRNAs increased $24 \mathrm{~h}$ post $\mathrm{PGF}_{2} \alpha$ administration}

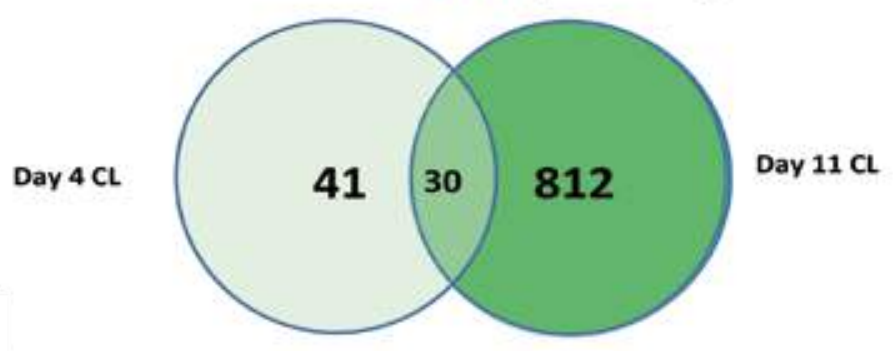

Fig. 1. Venn diagram depicting overlap and specificity in PGF2 $\alpha$-induced gene expression changes (number of mRNAs; relative to $0 \mathrm{~h}$ time point) in day 4 (PGF2 $\alpha$ refractory) vs. day 11 (PGF2 $\alpha$ responsive) corpora lutea $(\mathrm{CL})$ collected at 4 and $24 \mathrm{~h}$ after PGF $2 \alpha$ administration (Mondal, et al. 2011). 
The intercellular mechanisms contributing to the more robust and persistent gene expression response to PGF $2 \alpha$, which is characteristic of PGF $2 \alpha$ responsive versus $d 4$ (PGF2 $\alpha$ refractory) $\mathrm{CL}$, is not completely understood. However, it is plausible that infiltration of immune cells at this stage, along with differences in gene expression in specific cell populations, is involved. Gene expression profile data provide evidence for infiltration and/or activation of many immune cell types in the CL including macrophages (CD14), T lymphocytes (CD1B, CD2, CD3E, CD3G, CD8, CD48, CD69), dendritic cells (CD83), and natural killer cells (CD2, CD244) (Mondal, et al. 2011, Skarzynski, et al. 2013) (Fig. 2). Furthermore, the up-regulation of numerous endothelial adhesion molecules such as CCL2 (Mondal, et al. 2011, Tsai, et al. 1997), SELE, SELP, ICAM, and several integrins most likely facilitates leukocyte recruitment and endothelial transmigration (Bowen, et al. 1999, Petri, et al. 2008). Most of these genes were either not at all induced on $d 4$ or the genes were stimulated to a lesser extent than on d 11 (CD14, CD69, and CD3E). Notably, unlike in the mature gland, immune-related genes were not found any longer $24 \mathrm{~h}$ post PGF2 $\alpha$ in the early, d 4 CL (Fig. 2) (Mondal, et al. 2011).

\section{Angiogenesis related genes induced by prostaglandin F2 $\alpha$}

Zalman and colleagues (Zalman et al., 2012) identified an interesting group of PGF2 $\alpha$-regulated genes, genes that are known to be involved in angiogenesis (Table 2). This group of pro and antiangiogenic genes included vascular endothelial growth factor $A$ (VEGFA), fibrobast growth factor 2 (FGF2), pentraxin 3 (PTX3), thrombospondin 1, thrombospondin 2 (gene symbol THBS; protein abbreviation, TSP), their CD36 receptor and transforming growth factor, beta 1 (TGFB1) (Table 2). The two pro-angiogenic factors exhibited distinct profiles: VEGFA was decreased by PGF $2 \alpha$ regardless of luteal stage and FGF2 expression (mRNA and protein) surged in the PGF2 $\alpha$-refractory d 4 CL. Conversely, inhibitors of FGF2 action, THBS 1 and 2, their receptor (CD36), and PTX3 were up-regulated by PGF2 $\alpha$ specifically in d $11 \mathrm{CL}$ undergoing luteolysis (Zalman, et al. 2012). These results therefore suggest a potential functional relationship between FGF2 activity and the luteolytic response to PGF2 $\alpha$. Importantly, the angiogenic genes regulated by PGF $2 \alpha$ are expressed in both luteal endothelial and steroidogenic cells (Fig. 3). Data presented in Fig. 3 also show that at early luteal stage FGF2 is expressed at higher levels in endothelial cells than in steroidogenic cells and that the two THBSs genes exhibit preferential cell localization; while THBS1 is localized mainly to endothelial cells, THBS2 is higher in steroidogenic cells (Fig. 3).

Table 2. Prostaglandin F $2 \alpha$ - regulated genes that are involved in angiogenesis, in the bovine corpus luteum.

\begin{tabular}{ll}
\hline Pro - angiogenic genes & Anti - angiogenic genes \\
\hline VEGFA (decreased d4 \&11) & PTX3 (increased only on d11) \\
FGF2 (major increase on d4) & THBS1 (increased only on d11) \\
& THBS2 (increased only on d11) \\
& CD36 receptor (increased only on d11) \\
& TGFB1 (increased only on d11) \\
\hline
\end{tabular}

VEGFA - Vascular endothelial growth factor A; FGF2 - (Basic) fibroblast growth factor -2; PTX3- pentraxin 3, long; THBS1 - Thrombospondin 1; THBS2 - Thrombospondin 2; TGFB1- transforming growth factor, beta 1.

Data are from (Hou, et al. 2008, Maroni and Davis 2011, Mondal, et al. 2011, Skarzynski, et al. 2013, Zalman, et al. 2012). 


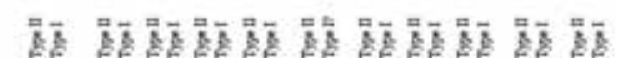

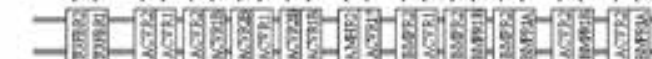

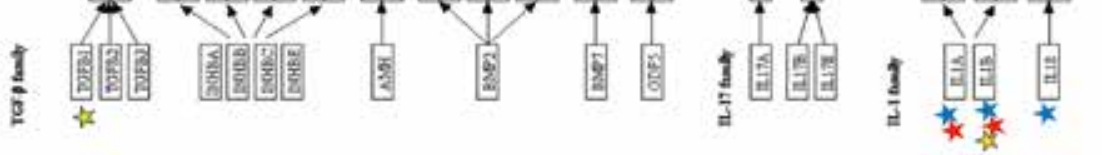

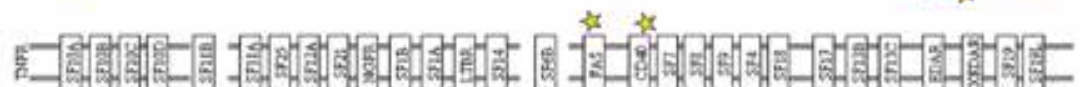

-

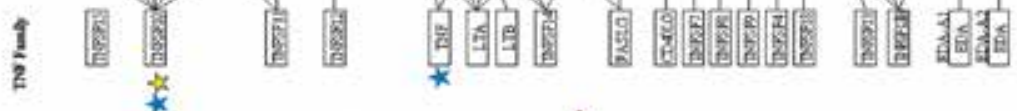

H-

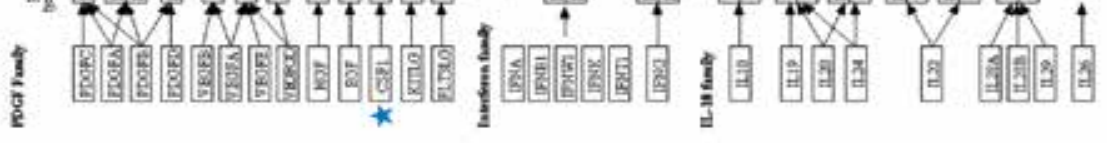

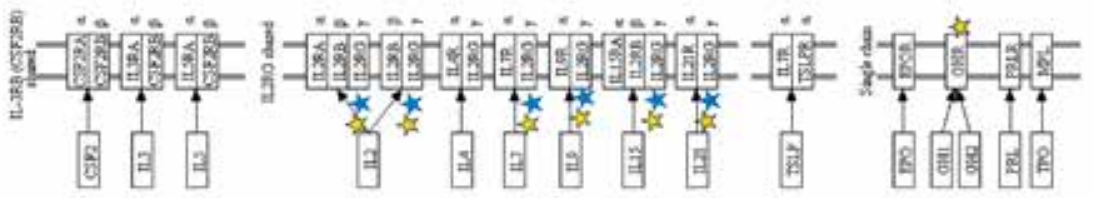

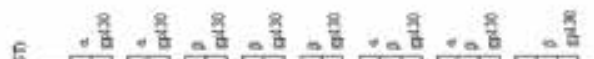

1-

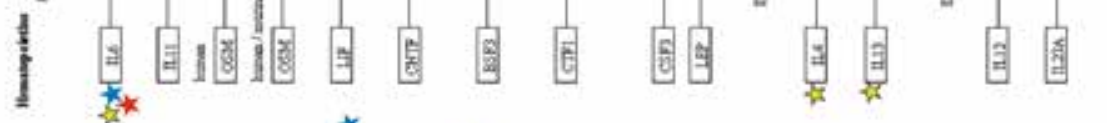

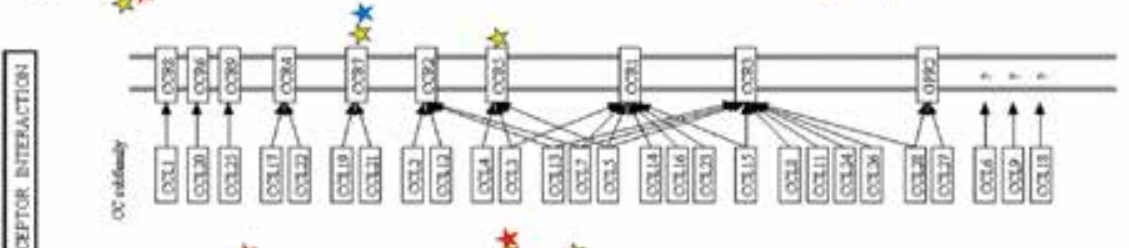

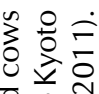

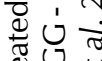

号

잉

N

Uㄴㅇㅇ

$\leq$

드응 웅

可 专

흠․․

둥

증

$\infty$

I

능

월

은 눈

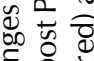

등ํำ

둔

눙ㅎㅇ

突

$\frac{00}{0}$

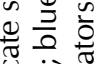

完:

휸

in

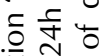

䄼

离 $\frac{\pi}{0} \frac{\pi}{0}$

흥 응

눙

宛

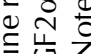

응

范范

远

咅 +

才语

बें

政

党跑

$\circlearrowleft$ 它

Ш 仓 巳

고은

인 
A.

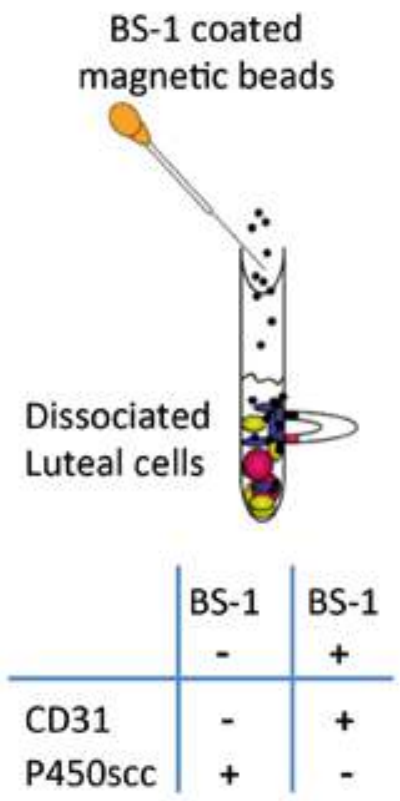

Enriched EC
B.
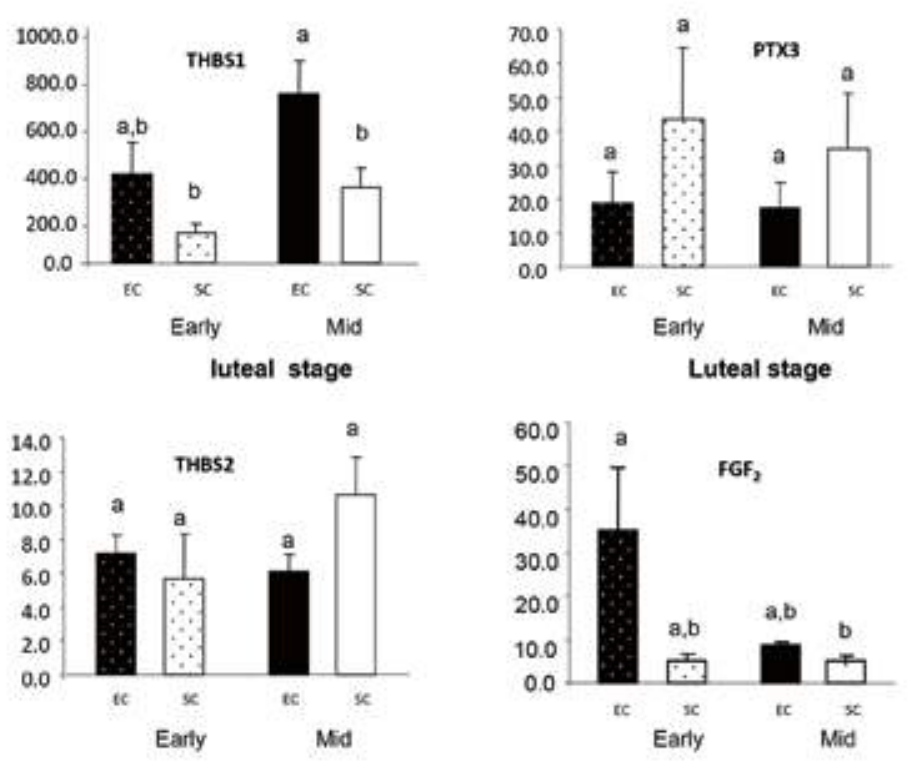

Luteal stage

Luteal stage

Fig. 3. A. Luteal cell enrichment; enzymatically dispersed CL cells were suspended and mixed with beads coated by BS-1 (Bandeiraea Simplicifolia Lectin-1). Positive cells (cells adhering to BS-1-coated magnetic beads) exhibit endothelial markers, and BS-1 negative cells (nonadhering cells) exhibit steroidogenic markers. Cross contamination between enriched cell populations did not exceed 10\% (Levy, et al. 2001). B. Messenger RNA levels for FGF2, PTX3, THBS1, and THBS2 in steroidogenic cells (SC) and endothelial cells (EC) enriched from bovine CL collected at early (before day 5) and midluteal stages (days 8-12). At least four $\mathrm{CL}$ were utilized for each luteal stage. Data were normalized relative to the abundance of GPDH mRNA in the same samples. Different letters denote statistical differences $(P<0.05)$ (Zalman, et al. 2012).

THBS1 was also augmented in sheep CL during natural luteolysis (Romero, et al. 2013); other genes that were lowered in regressing $\mathrm{CL}$ of the ewe, such as the $\mathrm{LH}$ receptor (LHR) and VEGFA, were similarly down-regulated in PGF $2 \alpha$-treated cows at mid cycle (Mondal, et al. 2011, Neuvians, et al. 2004).

The fact that many angiogenesis-modulating genes were dynamically and stage specifically regulated by PGF2 $\alpha$ is not surprising, the $\mathrm{CL}$ is a highly vascularized gland and is a site of extensive angiogenesis (Berisha and Schams 2005, Fraser and Wulff 2001). In addition to its known effects on endothelial cells, studies have shown that FGF2 also affects granulosa and luteal cell functions (Grasselli, et al. 2003, Grazul-Bilska, et al. 1995, Zalman, et al. 2012), illustrating the pleiotropic actions of this growth factor.

The activity of FGF2 in the extracellular milieu is controlled by its interaction with various extracellular matrix proteins, where PTX3 and THBSs are prominent examples. Recent observations have shown that PTX3 binds FGF2 and inhibits its angiogenic activity on endothelial cells (Leali, et al. 2009). PTX3 has nonredundant functions under various 
physiopathological conditions and may serve as a mechanism for amplifying inflammation, innate immunity, and tissue remodeling (Inforzato, et al. 2011). Whereas PTX3 mRNA and protein concentrations were elevated in the $\mathrm{d} 11 \mathrm{CL}$, in sheep this gene was inhibited during luteolysis (Romero, et al. 2013). The reason for this discrepancy is not clear. The other potent inhibitors of FGF2 actions that were upregulated by PGF2 $\alpha$ in $\mathrm{CL}$ undergoing luteolysis were TSPs. TSPs are a family of extracellular matrix proteins whose inhibitory effects on angiogenesis have been established in numerous experimental models (Grant and Kalluri 2005, Iruela-Arispe, et al. 2004, Lawler 2002, Vailhe and Feige 2003). Among TSP family members, TSP-2 has an equivalent domain structure similar to TSP-1 and shares most of its functions (Adams and Lawler 2004). As noted above, both THBS1 and 2 were induced by PGF $2 \alpha$ only in mature glands. TSP-1 binds to a variety of proteins on the cell surface and in the extracellular milieu. Therefore, it can exert its antiangiogenic activity through multiple mechanisms involving different active sequences in different domains (Iruela-Arispe, et al. 2004). The main antiangiogenic site of TSP-1 has been identified in type I repeats that interact with the CD36 receptor and HSPGs (Bornstein 2009). Another antiangiogenic site was found in the type III repeats of TSP-1, which inhibits angiogenesis by binding and sequestering FGF-2 (Colombo, et al. 2010). Therefore, the PGF2 $\alpha$-stimulated increase in THBS1, THBS2, and CD 36 on $d 11$ and not on the $\mathrm{d} 4$ gland implies that TSPs may play an inhibitory role in CL by inhibiting FGF-2 actions. Importantly, it was reported that these factors influenced the angiogenic properties of luteal endothelial cells. FGF2 dose-dependently enhanced their cell migration and proliferation, whereas TSP1 and PTX3 inhibited FGF2 actions; TSP-1 also induced cell death under basal conditions (Zalman, et al. 2012).

TSP-1 may also contribute to luteolysis by converting latent TGFB1 into its biologically active form (Young and Murphy-Ullrich 2004). TGFB1 is produced in a latent form consisting of the mature TGFB1 dimer and a noncovalently related latency-associated peptide (LAP). A conserved sequence near the $\mathrm{N}$ terminus of LAP was identified as a site of TSP-1 binding to the latent complex (Young and Murphy-Ullrich 2004). TGFB1 peptide was shown to reduce luteal endothelial cell proliferation and migration, and it disrupted the formation of capillary-like structures (Maroni and Davis 2011). It is noteworthy that the TGFB1 gene and its downstream target, serpin 1, were shown to be upregulated during luteal regression by PGF2a in sheep and cows (Hou, et al. 2008, Mondal, et al. 2011, Romero, et al. 2013).

The resulting destabilization of blood vessels in d $11 \mathrm{CL}$ (because of the actions of TSPs, PTX3, and TGFB1) is expected to weaken the gland and reduce its hormonal output. Additionally, these events, along with the vasoconstrictive and antisteroidogenic actions of endothelin-1 (Meidan and Levy 2007, Shirasuna, et al. 2006), are expected to further reduce $\mathrm{P}_{4}$ secretion and promote regression of mature $\mathrm{CL}$.

To mimic the physiological concentration and pulsatile release of PGF2 $\alpha$ that occurs during natural luteolysis, the Wiltbank laboratory (Atli, et al. 2012) employed multiple low-dose pulses of PGF $2 \alpha$. They found that although the initial PGF $2 \alpha$ pulse had a distinct effect on luteal mRNA concentrations, the second and ensuing pulses of PGF $2 \alpha$ established the distinct patterns of gene expression that result in luteolysis. Importantly, at least two pulses were needed to induce the pattern of pro-angiogenic genes mentioned above (VEGFA and FGF2) that were observed in the luteolytic CL (Mondal, et al. 2011). The study of Atli and colleagues also showed that repeated exposure to PGF $2 \alpha$ is necessary for continuance of luteolytic pathways within $\mathrm{CL}$, consistent with the concept of auto-amplification (Atli, et al. 2012). Such amplification also distinguishes the responses to PGF $2 \alpha$ at midcycle from CL at an early luteal stage (Mondal, et al. 2011). The need for several PGF $2 \alpha$ pulses (five in this case) at a precise frequency to induce luteal regression in sheep was also reported (McCracken, et al. 2012). 


\section{Corpus luteum maintenance: the roles of interferon tau and prostaglandin $E_{2}$}

Maintenance of $C L$ in early pregnancy, also known as maternal recognition of pregnancy, is a critical rate-limiting step in the reproductive efficiency of ruminant species (Bazer, et al. 2012, Bridges, et al. 2013, Evans and Walsh 2011, Matsuyama, et al. 2012, Utt and Day 2013). Early observations showed that in ruminants, hysterectomy itself (being the source of PGF $2 \alpha$ ) prolongs the luteal life span to a length approximating the gestation period (Casida and Wiltbank 1956, Moor and Rowson 1964). Levels of circulating PGFM (PGF2 $\alpha$ metabolite) differ in pregnant vs cyclic ruminants. Low-level PGFM episodes were present in cyclic and pregnant cows on Days 14 and 16 after oestrus, and high amplitude episodes occurred in non-pregnant cows during luteal regression (Lafrance and Goff 1985, Parkinson and Lamming 1990). Pregnant cows showed a significant depression of pPGFM amplitude, but not in frequency of episodes at the expected time of luteal regression regression (Lafrance and Goff 1985, Parkinson and Lamming 1990). Furthermore PGFM response to oxytocin challenge, showed lower mean values in pregnant than cyclic animals (Parkinson, et al. 1990). Also in ewes the presence of the conceptus locally inhibits the endometrial PGF2 $\alpha$ production following oxytocin challenge (Payne and Lamming 1994). While these studies tend to suggest the existence of a mechanism that attenuates uterine PGF2 $\alpha$ production and/or release during pregnancy, other studies had noted unchanged or even increased PGF $2 \alpha$ in uteri of pregnant animals (Burgess, et al. 1990, Silvia, et al. 1984), this discrepancy may results from technical difficulties in sampling or other reasons which are not clear.

The main signal for maternal recognition of pregnancy in these species is a type I interferon later known as IFN Tau (Bazer, et al. 1997, Roberts 1996). The coordinated actions of $\mathrm{P}_{4}$ and embryonic/placental hormones regulate reciprocal fetal-maternal interactions required for establishing and maintaining pregnancy. Indeed, a positive relationship exists between concentrations of $\mathrm{P}_{4}$ in the early luteal phase and IFNT synthesis (Kerbler, et al. 1997) and subsequent embryo development (Spencer, et al. 2007, Thatcher, et al. 2001). IFNT is secreted by ruminant trophectoderm cells during elongation of the early embryo, and it has been shown to be the signal for luteal maintenance during early pregnancy (Bazer, et al. 1997, Roberts 1996). IFNT acts in a paracrine manner to prevent the expression of estrogen receptor alpha (ESR1) and oxytocin receptors (OTR) in the endometrial luminal epithelium and superficial glandular epithelium, thereby altering the release of luteolytic pulses of PGF2 $\alpha$ (Spencer, et al. 2007). IFNT also stimulates interferon-stimulated genes (ISGs) in the uterus (Choi, et al. 2001, Johnson, et al. 2002, Ott, et al. 1998), and in peripheral tissues including the CL (Bott, et al. 2010, Oliveira, et al. 2008), peripheral blood cells (Gifford, et al. 2007, Shirasuna, et al. 2012), and the mammary gland (Yang, et al. 2010). Thus, IFNT might prevent luteal regression by acting directly on $\mathrm{CL}$ and this action could be independent of, or synergistic with, the actions of IFNT on uterine PGF $2 \alpha$ secretion. The expression of ISG15 was greater in CL from pregnant ewes (Oliveira, et al. 2008) and during uterine vein infusion of rolFNT in ewes (Bott, et al. 2010 ) or cows (Yang, et al. 2010). Recently, it was shown that endocrine delivery of rolFNT, via the uterine or jugular vein, protects the ovine $C L$ from the luteolytic actions of PGF $2 \alpha$ (Antoniazzi, et al. 2013). Ewes treated with rolFNT maintained intraluteal and circulating $\mathrm{P}_{4}$, maintained luteal volume, and had greater expression of genes for cell survival (Antoniazzi, et al. 2013). Romero et al. (Romero, et al. 2013) identified genes stabilized during pregnancy in ovine $C L$ that were otherwise downregulated in luteolysis - IL6, PTX3, THBS1, LHR, and VEGFA. To determine how these genes are directly regulated by various hormonal treatments in sheep, small, large, and mixed luteal cells were employed. Whereas culture with PGF $2 \alpha$ and oxytocin downregulated these genes, inducing luteolytic-like effects, IFNT did not mimic pregnancy by increasing those genes in the mixed cell preparations, and only culture of large 
luteal cells with IFNT induced upregulation in a few genes (Romero, et al. 2013). The data regarding the direct, endocrine actions of INFT in bovine species are even less conclusive. Some studies showed that IFNT, when cultured with bovine luteal cells, can induce ISG-15 (Kowalczyk-Zieba, et al. 2012, Nitta, et al. 2011), and others reported that explants of CL from d 15 of the estrous cycle did not express ISG15 after being cultured with 100ng/mL of IFNT for 24h, whereas the same treatment enhanced ISG15 in endometrial explants (Yang, et al. 2010). Another observation was made by Nitta et al. (Nitta, et al. 2011), who reported that treatment of endothelial cells, isolated from internal iliac lymphatic vessels, with IFNT stimulated their proliferation and the mRNA expression of VEGFC and ISG 15. But, a convincing proof for IFNT affecting bovine luteal function per se by acting on either steroidogenic, endothelial, or immune cells is lacking at this time. Therefore, although it is clear that IFNT is the embryonic signal for maternal recognition of pregnancy in ruminants, determining the mechanisms that result in luteal maintenance are poorly understood and require further research.

Other pregnancy-associated factors, such as $\mathrm{PGE}_{2}$, could induce processes that are important for maintenance of CL in pregnancy (Lee, et al. 2012a, Weems, et al. 2011, Weems, et al. 2012). $\mathrm{PGE}_{2}$ has long been suggested as a potent luteotrophic factor that can induce $\mathrm{P}_{4}$ production (Miyamoto, et al. 1993, Shelton, et al. 1990), furthermore, intra-luteal implants containing PGE $_{2}$ were shown to maintained luteal weights and circulating $\mathrm{P}_{4}$ on days 14-19 in cows (Weems,

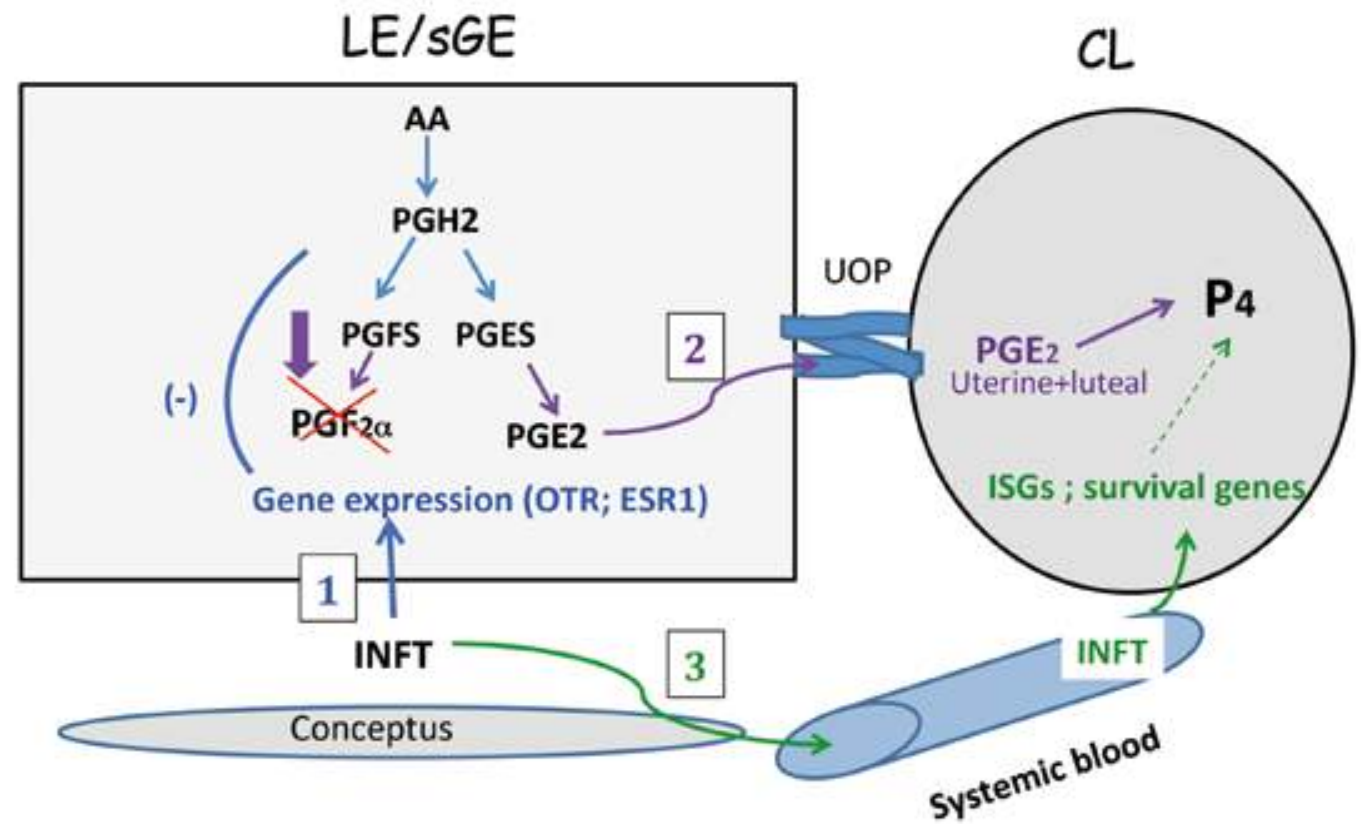

Fig. 4. Simplified model describing three potential pathways involved in $\mathrm{CL}$ maintenance by interferon tau (IFNT). 1. IFNT acts on the endometrial luminal epithelium (LE) and the superficial ductal glandular epithelium (sGE) to inhibit transcription of the estrogen receptor alpha gene (ESR1) directly and the oxytocin receptor (OTR) gene indirectly to abrogate synthesis of luteolytic PGF2 $\alpha$. 2. IFNT reduces PGFS and the ability of the prostaglandin transporter (PGT) to interact with PGF2 $\alpha$, thus abrogating PGF $2 \alpha$ pulses. In addition, IFNT increases the production of $\mathrm{PGE}_{2}$ in endometrial tissue that is transported from the uterus to the ovary through the $U O P$ (utero pvarian plexus), thus inducing luteal $\mathrm{PGE}_{2}$, which maintains $\mathrm{CL}$ function. 3. Endocrine delivery of IFNT, by interacting directly with the $\mathrm{CL}$, protects the gland from undergoing luteolysis by a mechanism involving ISGs and survival genes. For the list of references supporting these actions, please refer to the text. 
et al. 2011, Weems, et al. 2012). Arosh et al. reported major changes in PGE $_{2}$ and PGF2 $\alpha$ synthesis and in their receptors induced by intrauterine IFNT infusion in the endometrium, myometrium, and CL of cattle (Arosh, et al. 2004b). IFNT increased COX-2 mRNA and protein expression in endometrium. IFNT also decreases PTGFS in the endometrium and myometrium, suggesting that in the bovine uterus, IFNT could directly act to lower PGF2 $\alpha$ synthesis (Arosh, et al. 2004b). Importantly, no influence of IFNT on the luteal expression of COX-2 and PTGFS could be detected. In a later study, an additional mechanism for reduced PGF2 $\alpha$ pulses during pregnancy was suggested - IFNT alters phosphorylation of PGT protein, resulting in the inhibition of PGT-mediated transport of PGF2 $\alpha$ (Banu, et al. 2010). Besides prostaglandin metabolizing enzymes, PGE receptors (PTGER2 and PTGER4) were stimulated by IFNT, thus enhancing PGE ${ }_{2}$ effects (Lee, et al. 2012a). Another study that emphasized the role of $\mathrm{PGE}_{2}$ during pregnancy was carried out by Lee et al. (Lee, et al. 2012b), who showed that prostaglandin biosynthesis in $\mathrm{CL}$ is directed toward $\mathrm{PGE}_{2}$ in the pregnant ewe. They showed that this was achieved by induction of a specific PGE synthase in the CL of pregnant ewes; consequently, concentrations of intraluteal $\mathrm{PGE}_{2}$ were greater than in cyclic animals. Moreover, the $\mathrm{PGE}_{2}$ receptors PTGER2 and PTGER4 were also induced in CL from days 12 to 16 of pregnancy. These findings indicated that the $\mathrm{CL}$ secretes more $\mathrm{PGE}_{2}$ during the establishment of pregnancy. Whether or not IFNT regulates luteal prostaglandin synthesis was not determined in this study.

In debating the effects of pregnancy on the $C L$, a fundamental question arises: is the $C L$ of pregnancy different from the CL of midcycle? And if so, is it due to IFNT exposure? The CL of early pregnancy does not exhibit greater steroidogenic capacity and progesterone concentrations in pregnant versus cyclic animals are comparable (Magata, et al. 2012, Parkinson and Lamming 1990). In addition, there is no new wave of angiogenesis in the CL of early pregnancy, since endothelial or pericyte /smooth muscle cell markers remained similar in the CL from day 16 of the estrous cycle to day 40 of early pregnancy (Beindorff, et al. 2010). Accordingly, no significant change occurred in the expression of VEGFA between midcycle and pregnant CL (Beindorff, et al. 2010, Magata, et al. 2012). Furthermore, a recent study by Romero et al. (Romero, et al. 2013) examined the transcriptome of cyclic vs pregnant sheep $\mathrm{CL}$; In addition to the battery of IFNT-stimulated genes, no specific pregnancy-associated genes were noted. Rather, luteolysisrelated genes such as IL6, PTX3, THBS1, LHR, and VEGFA were inversely regulated in CL of pregnant ewe. The study comparing cyclic, pregnant, and persistent $\mathrm{CL}$ (approx. 30 days post ovulation, noninseminated cows) is especially relevant in this context (Magata, et al. 2012). In support of above mentioned conclusions, comparisons of these types of $\mathrm{CL}$ showed that persistent $C L$ and that of pregnant cow had similar levels of steroidogenic enzymes, VEGFA, VEGFC, and PGFS. Interferon-induced gene-OAS-1 was higher only in pregnant CL, indicating exposure to IFNT. PGES was an exception; PGES was observed in CL of pregnant animal and not in cyclic or persistent luteal tissue (Magata, et al. 2012), which was also reported by (Lee, et al. 2012b). Is it a direct or indirect effect exerted by IFNT in CL? Lee at al. (Lee, et al. 2012b) proposed that endometrial $\mathrm{PGE}_{2}$ stimulated by pregnancy is transported locally to the ovary, which increases luteal $\mathrm{PGE}_{2}$ biosynthesis, but this has not yet been experimentally proven. Evidently CL of pregnant animal expresses ISGs, but so do many other peripheral tissues, whether ISGs affect luteal function is unclear at present.

Reviewing the findings published thus far support the notion that three potential pathways (Fig. 4) may be involved in luteal maintenance by IFNT: First, the classical mechanism whereby IFNT changes uterine gene expression, resulting in reduced pulses of PGF2 $\alpha$ and thus prevents luteolysis (Dorniak, et al. 2013, Gifford, et al. 2007, Knickerbocker, et al. 1986, Spencer, et al. 2007, Thatcher, et al. 2001). Second, IFNT decreases uterine PTGFS; INFT also increases the transported of $\mathrm{PGE}_{2}$ from the uterus to the ovary through the UOP, thus inducing luteal $\mathrm{PGE}_{2}$, 
which maintains luteal function (Arosh, et al. 2004b, Asselin, et al. 1997, Lee, et al. 2012a, Wasielak, et al. 2009, Weems, et al. 2011, Weems, et al. 2012). Third, recent evidence indicates that the endocrine mode of IFNT action, by interacting directly with the CL, protects the gland from undergoing luteolysis by a mechanism involving ISGs and survival genes (Antoniazzi, et al. 2013, Bott, et al. 2010, Gifford, et al. 2007, Hansen, et al. 2010, Oliveira, et al. 2008).

Are these pathways independent or complementary? And do these pathways exist and operate similarly in ewes and cows? The answers to these and other open questions will provide in the future a rational basis for developing methods to enhance maintenance of the ruminant $\mathrm{CL}$ during early pregnancy.

\section{References}

Adams, JC, and J Lawler 2004 The thrombospondins. Int J Biochem Cell Biol 36 961-968.

Antoniazzi, AQ, BT Webb, J Romero, RL Ashley, NP Smirnova, LE Henkes, RC Bott, JF Oliveira, GD Niswender, FW Bazer, and TR Hansen 2013 Endocrine delivery of interferon tau protects the corpus luteum from prostaglandin F2 alpha-induced luteolysis in ewes. Biol Reprod 88144.

Arosh, JA, SK Banu, P Chapdelaine, E Madore, J Sirois, and MA Fortier 2004a Prostaglandin biosynthesis, transport, and signaling in corpus luteum: a basis for autoregulation of luteal function. Endocrinology 145 2551-2560.

Arosh, JA, SK Banu, S Kimmins, P Chapdelaine, LA Maclaren, and MA Fortier 2004b Effect of interferon-tau on prostaglandin biosynthesis, transport, and signaling at the time of maternal recognition of pregnancy in cattle: evidence of polycrine actions of prostaglandin E2. Endocrinology 145 5280-5293.

Asselin, E, D Lacroix, and MA Fortier 1997 IFN-tau increases PGE2 production and COX-2 gene expression in the bovine endometrium in vitro. Mol Cell Endocrinol 132 117-126.

Atli, MO, RW Bender, V Mehta, MR Bastos, W Luo, CM Vezina, and MC Wiltbank 2012 Patterns of gene expression in the bovine corpus luteum following repeated intrauterine infusions of low doses of prostaglandin F2alpha. Biol Reprod 86130.

Banu, SK, J Lee, SD Stephen, TK Nithy, and JA Arosh 2010 Interferon tau regulates PGF2alpha release from the ovine endometrial epithelial cells via activation of novel JAK/EGFR/ERK/EGR-1 pathways. Mol Endocrinol 24 2315-2330.

Bazer, FW, TE Spencer, and TL Ott 1997 Interferon tau: a novel pregnancy recognition signal. Am / Reprod Immunol 37 412-420.

Bazer, FW, TE Spencer, and WW Thatcher 2012 Growth and development of the ovine conceptus. J Anim Sci 90 159-170.

Beindorff, N, K Nagai, K Shirasuna, K Herzog, K Hoeffmann, M Sasaki, H Bollwein, and A Miyamoto 2010 Vascular changes in the corpus luteum during early pregnancy in the cow. J Reprod Dev 56 263-270.

Berisha, B, and D Schams 2005 Ovarian function in ruminants. Domest Anim Endocrinol 29 305-317.
Berisha, B, F Sinowatz, and D Schams 2004 Expression and localization of fibroblast growth factor (FGF) family members during the final growth of bovine ovarian follicles. Mol Reprod Dev 67 162-171.

Bornstein, P 2009 Thrombospondins function as regulators of angiogenesis. J Cell Commun Signal $\mathbf{3}$ 189-200.

Bott, RC, RL Ashley, LE Henkes, AQ Antoniazzi, JE Bruemmer, GD Niswender, FW Bazer, TE Spencer, NP Smirnova, RV Anthony, and TR Hansen 2010 Uterine vein infusion of interferon tau (IFNT) extends luteal life span in ewes. Biol Reprod 82 725-735.

Bowen, JM, R Towns, JS Warren, and P Landis Keyes 1999 Luteal regression in the normally cycling rat: apoptosis, monocyte chemoattractant protein-1, and inflammatory cell involvement. Biol Reprod 60 740-746.

Bridges, GA, ML Day, TW Geary, and LH Cruppe 2013 Triennial Reproduction Symposium: deficiencies in the uterine environment and failure to support embryonic development. J Anim Sci 91 3002-3013.

Brusveen, DJ, AH Souza, and MC Wiltbank 2009 Effects of additional prostaglandin F2alpha and estradiol-17beta during Ovsynch in lactating dairy cows. J Dairy Sci 92 1412-1422.

Burgess, KM, MM Ralph, G Jenkin, and GD Thorburn 1990 Effect of oxytocin and estradiol on uterine prostaglandin release in nonpregnant and early-pregnant ewes. Biol Reprod 42 822-833.

Casida, LE, and JN Wiltbank 1956 Alteration of ovarian activity by hysterectomy. J. Animal Sci. 15134.

Choi, Y, GA Johnson, RC Burghardt, LR Berghman, MM Joyce, KM Taylor, MD Stewart, FW Bazer, and TE Spencer 2001 Interferon regulatory factor-two restricts expression of interferon-stimulated genes to the endometrial stroma and glandular epithelium of the ovine uterus. Biol Reprod 65 1038-1049.

Colombo, G, B Margosio, L Ragona, M Neves, S Bonifacio, DS Annis, M Stravalaci, S Tomaselli, R Giavazzi, M Rusnati, M Presta, L Zetta, DF Mosher, D Ribatti, M Gobbi, and G Taraboletti 2010 Non-peptidic thrombospondin-1 mimics as fibroblast growth factor-2 inhibitors: an integrated strategy for the development of new antiangiogenic compounds. J Biol Chem 285 8733-8742. 
Dorniak, P, FW Bazer, and TE Spencer 2013 Physiology and Endocrinology Symposium: biological role of interferon tau in endometrial function and conceptus elongation. J Anim Sci 91 1627-1638.

Evans, AC, and SW Walsh 2011 The physiology of multifactorial problems limiting the establishment of pregnancy in dairy cattle. Reprod Fertil Dev 24 233-237.

Fraser, HM, and C Wulff 2001 Angiogenesis in the primate ovary. Reprod Fertil Dev 13 557-566.

Ghanem, ME, T Nakao, K Nakatani, M Akita, and T Suzuki 2006 Milk progesterone profile at and after artificial insemination in repeat-breeding cows: effects on conception rate and embryonic death. Reprod Domest Anim 41 180-183.

Gifford, CA, K Racicot, DS Clark, KJ Austin, TR Hansen, MC Lucy, CJ Davies, and TL Ott 2007 Regulation of interferon-stimulated genes in peripheral blood leukocytes in pregnant and bred, nonpregnant dairy cows. J Dairy Sci 90 274-280.

Grant, MA, and R Kalluri 2005 Structural basis for the functions of endogenous angiogenesis inhibitors. Cold Spring Harb Symp Quant Biol 70 399-410.

Grasselli, F, M Tirelli, V Cavalli, S Bussolati, and C Tamanini 2003 VEGF, bFGF and swine granulosa cells: proliferation, steroidogenesis and $\mathrm{NO}$ production. Vet Res Commun 27 Suppl 1 233-235.

Grazul-Bilska, AT, DA Redmer, A Jablonka-Shariff, ME Biondini, and LP Reynolds 1995 Proliferation and progesterone production of ovine luteal cells from several stages of the estrous cycle: effects of fibroblast growth factors and luteinizing hormone. Can J Physiol Pharmacol 73 491-500.

Hansen, TR, KJ Austin, DJ Perry, JK Pru, MG Teixeira, and GA Johnson 1999 Mechanism of action of interferontau in the uterus during early pregnancy. J Reprod Fertil Suppl 54 329-339.

Hansen, TR, LK Henkes, RL Ashley, RC Bott, AQ Antoniazzi, and H Han 2010 Endocrine actions of interferon-tau in ruminants. Soc Reprod Fertil Supp/ 67 325-340.

Hayashi, K, A Miyamoto, A Konari, M Ohtani, and Y Fukui 2003 Effect of local interaction of reactive oxygen species with prostaglandin $F$ (2alpha) on the release of progesterone in ovine corpora lutea in vivo. Theriogenology 59 1335-1344.

Hou, X, EW Arvisais, C Jiang, DB Chen, SK Roy, JL Pate, TR Hansen, BR Rueda, and JS Davis 2008 Prostaglandin F2alpha stimulates the expression and secretion of transforming growth factor B1 via induction of the early growth response 1 gene (EGR1) in the bovine corpus luteum. Mol Endocrinol 22 403-414.

Inforzato, A, S Jaillon, F Moalli, E Barbati, E Bonavita, B Bottazzi, A Mantovani, and C Garlanda 2011 The long pentraxin PTX3 at the crossroads between innate immunity and tissue remodelling. Tissue Antigens 77 271-282.

Iruela-Arispe, ML, A Luque, and N Lee 2004 Thrombospondin modules and angiogenesis. Int J Biochem Cell Biol 36 1070-1078.

Johnson, GA, MM Joyce, SJ Yankey, TR Hansen, and TL Ott 2002 The Interferon Stimulated Genes (ISG) 17 and
Mx have different temporal and spatial expression in the ovine uterus suggesting more complex regulation of the Mx gene. J Endocrinol 174 R7-R11.

Kerbler, TL, MM Buhr, LT Jordan, KE Leslie, and JS Walton 1997 Relationship between maternal plasma progesterone concentration and interferon-tau synthesis by the conceptus in cattle. Theriogenology 47 703-714.

Knickerbocker, JJ, WW Thatcher, FW Bazer, DH Barron, and RM Roberts 1986 Inhibition of uterine prostaglandin-F2 alpha production by bovine conceptus secretory proteins. Prostaglandins 31 777-793.

Kowalczyk-Zieba, I, D Boruszewska, JS Saulnier-Blache, L Lopes Da Costa, K Jankowska, DJ Skarzynski, and I Woclawek-Potocka 2012 Lysophosphatidic acid action in the bovine corpus luteum -an in vitro study. J Reprod Dev 58 661-671.

Lafrance, M, and AK Goff 1985 Effect of pregnancy on oxytocin-induced release of prostaglandin F2 alpha in heifers. Biol Reprod 33 1113-1119.

Lawler, J 2002 Thrombospondin-1 as an endogenous inhibitor of angiogenesis and tumor growth. J Cell Mol Med 6 1-12.

Leali, D, P Alessi, D Coltrini, M Rusnati, L Zetta, and M Presta 2009 Fibroblast growth factor-2 antagonist and antiangiogenic activity of long-pentraxin 3-derived synthetic peptides. Curr Pharm Des 15 3577-3589.

Lee, J, SK Banu, TK Nithy, JA Stanley, and JA Arosh 2012a Early pregnancy induced expression of prostaglandin E2 receptors EP2 and EP4 in the ovine endometrium and regulated by interferon tau through multiple cell signaling pathways. Mol Cell Endocrinol 348 211-223.

Lee, J, JA McCracken, SK Banu, R Rodriguez, TK Nithy, and JA Arosh 2010 Transport of prostaglandin F(2alpha) pulses from the uterus to the ovary at the time of luteolysis in ruminants is regulated by prostaglandin transportermediated mechanisms. Endocrinology 151 3326-3335.

Lee, J, JA McCracken, JA Stanley, TK Nithy, SK Banu, and JA Arosh 2012b Intraluteal prostaglandin biosynthesis and signaling are selectively directed towards PGF2alpha during luteolysis but towards PGE2 during the establishment of pregnancy in sheep. Biol Reprod 8797.

Levy, N, M Gordin, R Mamluk, M Yanagisawa, MF Smith, JH Hampton, and R Meidan 2001 Distinct cellular localization and regulation of endothelin-1 and endothelin-converting enzyme- 1 expression in the bovine corpus luteum: implications for luteolysis. Endocrinology 142 5254-5260.

Magata, F, K Shirasuna, K Struve, K Herzog, T Shimizu, H Bollwein, and A Miyamoto 2012 Gene expressions in the persistent corpus luteum of postpartum dairy cows: distinct profiles from the corpora lutea of the estrous cycle and pregnancy. J Reprod Dev 58 445-452.

Maroni, D, and JS Davis 2011 TGFB1 disrupts the angiogenic potential of microvascular endothelial cells of the corpus luteum. J Cell Sci 124 2501-2510.

Martins, JP, RK Policelli, LM Neuder, W Raphael, and JR Pursley 2011 Effects of cloprostenol sodium at final prostaglandin F2alpha of Ovsynch on complete luteolysis and pregnancy per artificial insemination in lactating dairy cows. J Dairy Sci 94 2815-2824. 
Matsuyama, S, Y Sakaguchi, and K Kimura 2012 Relationship between plasma progesterone concentration and number of conceptuses and their growth in superovulated cattle. J Reprod Dev 58 609-614.

McCracken, JA, JC Carlson, ME Glew, JR Goding, DT Baird, K Green, and B Samuelsson 1972 Prostaglandin F 2 identified as a luteolytic hormone in sheep. Nat New Biol 238 129-134.

McCracken, JA, EE Custer, DT Schreiber, PC Tsang, CS Keator, and JA Arosh 2012 A new in vivo model for luteolysis using systemic pulsatile infusions of PGF(2alpha). Prostaglandins Other Lipid Mediat 97 90-96.

Meidan, R, E Klipper, T Gilboa, L Muller, and N Levy 2005 Endothelin-converting enzyme-1, abundance of isoforms a-d and identification of a novel alternatively spliced variant lacking a transmembrane domain. J Biol Chem 280 40867-40874.

Meidan, R, and N Levy 2007 The ovarian endothelin network: an evolving story. Trends Endocrinol Metab 18 379-385.

Miyamoto, A, K Shirasuna, T Shimizu, H Bollwein, and D Schams 2010 Regulation of corpus luteum development and maintenance: specific roles of angiogenesis and action of prostaglandin F2alpha. Soc Reprod Fertil Suppl 67 289-304.

Miyamoto, A, H von Lutzow, and D Schams 1993 Acute actions of prostaglandin F2 alpha, E2, and I2 in microdialyzed bovine corpus luteum in vitro. Biol Reprod 49 423-430.

Mondal, M, B Schilling, J Folger, JP Steibel, H Buchnick, Y Zalman, JJ Ireland, R Meidan, and GW Smith 2011 Deciphering the luteal transcriptome: potential mechanisms mediating stage-specific luteolytic response of the corpus luteum to prostaglandin Falpha. Physiol Genomics 43 447-456.

Moor, RM, and LE Rowson 1964 Influence of the Embryo and Uterus on Luteal Function in the Sheep. Nature 201 522-523.

Neuvians, TP, D Schams, B Berisha, and MW Pfaffl 2004 Involvement of pro-inflammatory cytokines, mediators of inflammation, and basic fibroblast growth factor in prostaglandin F2alpha-induced luteolysis in bovine corpus luteum. Biol Reprod 70 473-480.

Niswender, GD, JL Juengel, PJ Silva, MK Rollyson, and EW McIntush 2000 Mechanisms controlling the function and life span of the corpus luteum. Physiol Rev 80 1-29.

Nitta, A, K Shirasuna, S Haneda, M Matsui, T Shimizu, S Matsuyama, K Kimura, H Bollwein, and A Miyamoto 2011 Possible involvement of IFNT in lymphangiogenesis in the corpus luteum during the maternal recognition period in the cow. Reproduction 142 879-892.

O'Shea, JD, RJ Rodgers, and MJ D'Occhio 1989 Cellular composition of the cyclic corpus luteum of the cow. $J$ Reprod Fertil 85 483-487.

Oliveira, JF, LE Henkes, RL Ashley, SH Purcell, NP Smirnova, DN Veeramachaneni, RV Anthony, and TR Hansen 2008 Expression of interferon (IFN)-stimulated genes in extrauterine tissues during early pregnancy in sheep is the consequence of endocrine IFN-tau release from the uterine vein. Endocrinology 149 1252-1259.
Ott, TL, J Yin, AA Wiley, HT Kim, B Gerami-Naini, TE Spencer, FF Bartol, RC Burghardt, and FW Bazer 1998 Effects of the estrous cycle and early pregnancy on uterine expression of Mx protein in sheep (Ovis aries). Biol Reprod 59 784-794.

Parkinson, TJ, LJ Jenner, and GE Lamming 1990 Comparison of oxytocin/prostaglandin F-2 alpha interrelationships in cyclic and pregnant cows. J Reprod Fertil 90 337-345.

Parkinson, TJ, and GE Lamming 1990 Interrelationships between progesterone, 13,14-dihydro-15-keto PGF-2 alpha (PGFM) and LH in cyclic and early pregnant cows. J Reprod Fertil 90 221-233.

Payne, JH, and GE Lamming 1994 The direct influence of the embryo on uterine PGF2 alpha and PGE2 production in sheep. J Reprod Fertil 101 737-741.

Petri, B, M Phillipson, and P Kubes 2008 The physiology of leukocyte recruitment: an in vivo perspective. J Immunol 180 6439-6446.

Ribeiro, ES, RS Bisinotto, MG Favoreto, LT Martins, RL Cerri, FT Silvestre, LF Greco, WW Thatcher, and JE Santos 2012 Fertility in dairy cows following presynchronization and administering twice the luteolytic dose of prostaglandin F2alpha as one or two injections in the 5-day timed artificial insemination protocol. Theriogenology 78 273-284.

Roberts, RM 1996 Interferon-tau and pregnancy. J Interferon Cytokine Res 16 271-273.

Romero, JJ, AQ Antoniazzi, NP Smirnova, BT Webb, F Yu, JS Davis, and TR Hansen 2013 Pregnancy-associated genes contribute to antiluteolytic mechanisms in ovine corpus luteum. Physiol Genomics 45 1095-1108.

Schams, D, and B Berisha 2004 Regulation of corpus luteum function in cattle-an overview. Reprod Domest Anim 39 241-251.

Shelton, K, TJ Parkinson, MG Hunter, RW Kelly, and GE Lamming 1990 Prostaglandin E-2 as a potential luteotrophic agent during early pregnancy in cattle. J Reprod Fertil 90 11-17.

Shirasuna, K, A Nitta, J Sineenard, T Shimizu, H Bollwein, and A Miyamoto 2012 Vascular and immune regulation of corpus luteum development, maintenance, and regression in the cow. Domest Anim Endocrinol 43 198-211.

Shirasuna, K, S Watanabe, N Oki, MP Wijayagunawardane, M Matsui, M Ohtani, and A Miyamoto 2006 A cooperative action of endothelin-1 with prostaglandin F(2alpha) on luteal function in the cow. Domest Anim Endocrinol 31 186-196.

Silvia, WJ, JS Ottobre, and EK Inskeep 1984 Concentrations of prostaglandins E2, F2 alpha and 6-keto-prostaglandin F1 alpha in the utero-ovarian venous plasma of nonpregnant and early pregnant ewes. Biol Reprod 30 936-944.

Skarzynski, DJ, KK Piotrowska-Tomala, K Lukasik, A Galvao, S Farberov, Y Zalman, and R Meidan 2013 Growth and regression in bovine corpora lutea: regulation by local survival and death pathways. Reprod Domest Anim $\mathbf{4 8}$ Suppl 1 25-37.

Spencer, TE, and FW Bazer 2004 Conceptus signals for establishment and maintenance of pregnancy. Reprod Biol Endocrinol 249. 
Spencer, TE, GA Johnson, FW Bazer, and RC Burghardt 2007 Fetal-maternal interactions during the establishment of pregnancy in ruminants. Soc Reprod Fertil Suppl 64 379-396.

Thatcher, WW, FF Bartol, JJ Knickerbocker, JS Curl, D Wolfenson, FW Bazer, and RM Roberts 1984 Maternal recognition of pregnancy in cattle. J Dairy Sci 672797 2811.

Thatcher, WW, A Guzeloglu, R Mattos, M Binelli, TR Hansen, and JK Pru 2001 Uterine-conceptus interactions and reproductive failure in cattle. Theriogenology $\mathbf{5 6}$ 1435-1450.

Tsai, SJ, JL Juengel, and MC Wiltbank 1997 Hormonal regulation of monocyte chemoattractant protein-1 messenger ribonucleic acid expression in corpora lutea. Endocrinology 138 4517-4520.

Utt, MD, and ML Day 2013 Triennial Reproduction Symposium: the obstacle course to successful establishment of pregnancy in domestic livestock species. J Anim Sci 91 2993-2999.

Vailhe, B, and JJ Feige 2003 Thrombospondins as antiangiogenic therapeutic agents. Curr Pharm Des 9 583-588.

Wasielak, M, K Kaminska, and M Bogacki 2009 Effect of the conceptus on uterine prostaglandin-F2alpha and prostaglandin-E2 release and synthesis during the periimplantation period in the pig. Reprod Fertil Dev 21 709-717.

Weems, YS, JA Arreguin-Arevalo, TM Nett, RC Vann, SP Ford, PJ Bridges, TH Welsh, Jr., AW Lewis, DA Neuendorff, RD Randel, and CW Weems 2011 In vivo intra-luteal implants of prostaglandin (PG) $\mathrm{E}(1)$ or $\mathrm{E}(2)$ (PGE(1), PGE(2)) prevent luteolysis in cows. I. Luteal weight, circulating progesterone, mRNA for luteal luteinizing hormone $(\mathrm{LH})$ receptor, and occupied and unoccupied luteal receptors for LH. Prostaglandins Other Lipid Mediat 95 35-44.

Weems, YS, PJ Bridges, M Jeoung, JA Arreguin-Arevalo, TM Nett, RC Vann, SP Ford, AW Lewis, DA Neuendorff, TH Welsh, Jr., RD Randel, and CW Weems 2012 In vivo intra-luteal implants of prostaglandin (PG) E1 or E2 (PGE1, PGE2) prevent luteolysis in cows. II: mRNA for PGF2alpha, EP1, EP2, EP3 (A-D), EP3A, EP3B, EP3C, EP3D, and EP4 prostanoid receptors in luteal tissue. Prostaglandins Other Lipid Mediat 97 60-65.

Wiltbank, MC 1994 Cell types and hormonal mechanisms associated with mid-cycle corpus luteum function. J Anim Sci 72 1873-1883.

Wiltbank, MC, and JS Ottobre 2003 Regulation of intraluteal production of prostaglandins. Reprod Biol Endocrinol 191.

Yang, L, XL Wang, PC Wan, LY Zhang, Y Wu, DW Tang, and SM Zeng 2010 Up-regulation of expression of interferonstimulated gene 15 in the bovine corpus luteum during early pregnancy. J Dairy Sci 93 1000-1011.

Young, GD, and JE Murphy-UIIrich 2004 Molecular interactions that confer latency to transforming growth factor-beta. J Biol Chem 279 38032-38039.

Zalman, Y, E Klipper, S Farberov, M Mondal, G Wee, JK Folger, GW Smith, and R Meidan 2012 Regulation of angiogenesis-related prostaglandin f2alpha-induced genes in the bovine corpus luteum. Biol Reprod 8692. 